\title{
Co-delivery of Phagocytosis Checkpoint Silencer and Stimulator of Interferon Genes Agonist for Synergetic Cancer Immunotherapy
}

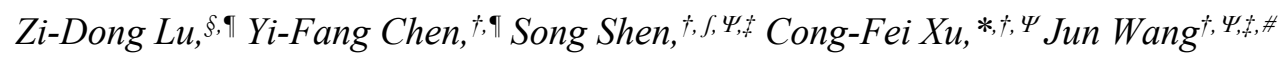

$\S$ School of Medicine, South China University of Technology, Guangzhou 510006, P.R. China

$\dagger$ School of Biomedical Sciences and Engineering, South China University of Technology, Guangzhou International Campus, Guangzhou 511442, P.R. China

` Shenzhen Bay Laboratory, Shenzhen 518132, P. R. China

${ }^{\Psi}$ National Engineering Research Center for Tissue Restoration and Reconstruction, South China University of Technology, Guangzhou 510006, P.R. China

$\$$ Key Laboratory of Biomedical Engineering of Guangdong Province, and Innovation Center for Tissue Restoration and Reconstruction, South China University of Technology, Guangzhou 510006, P.R. China

\# Key Laboratory of Biomedical Materials and Engineering of the Ministry of Education, South China University of Technology, Guangzhou 510006, P.R. China

* Corresponding Author: Prof. Cong-Fei Xu (xucf@scut.edu.cn) 


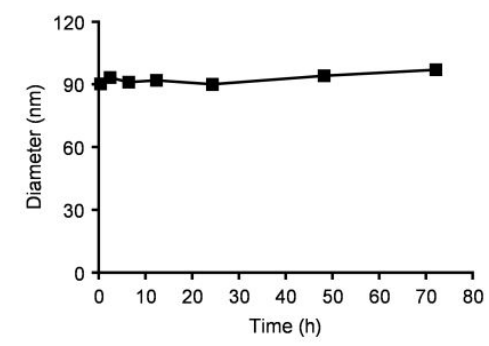

Figure S1. The stability of $\mathbf{N P}_{\text {sisIRPa/cGAMP }}$ in solution. $\mathrm{NP}_{\text {siSIRP } / \mathrm{cGAMP}}$ was incubated in PBS supplemented with $10 \% \mathrm{FBS}$, and the diameter of $\mathrm{NP}_{\text {sisIRP } \alpha / \mathrm{cGAMP}}$ was detected by Zetasizer Nano ZS90 at different time points.

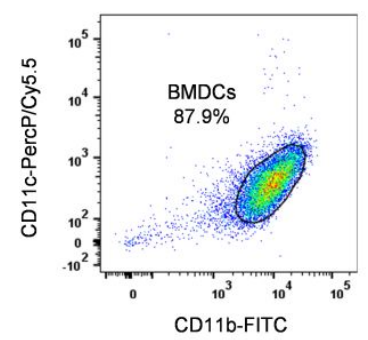

Figure S2. The percentage of CD11 $b^{+}$CD11 $c^{+}$BMDCs in our cultured cells. The cells were labeled with FITC-conjugated anti-CD11b and PerCP/Cy5.5-conjugated anti-CD11c before being analyzed by flow cytometry.

A

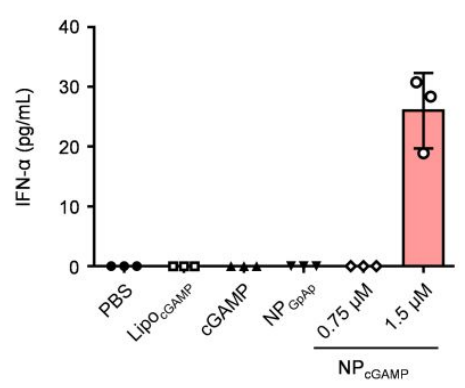

B

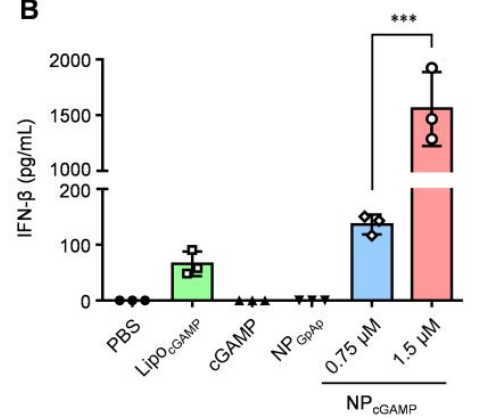

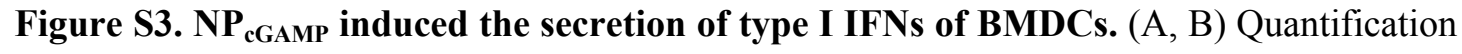
of the concentrations of IFN- $\alpha$ (A) or $\beta$ (B) in the culture supernatant of BMDCs by ELISA. BMDCs were transfected with $\mathrm{NP}_{\text {cGAMP }}(0.75$ or $1.5 \mu \mathrm{M}$ cGAMP) or other controls. The data are shown as the mean \pm s.d. of $\mathrm{n}=3$. Significant differences are indicated by $* * * P<0.001$, 
one-way ANOVA with Tukey's multiple comparisons test.
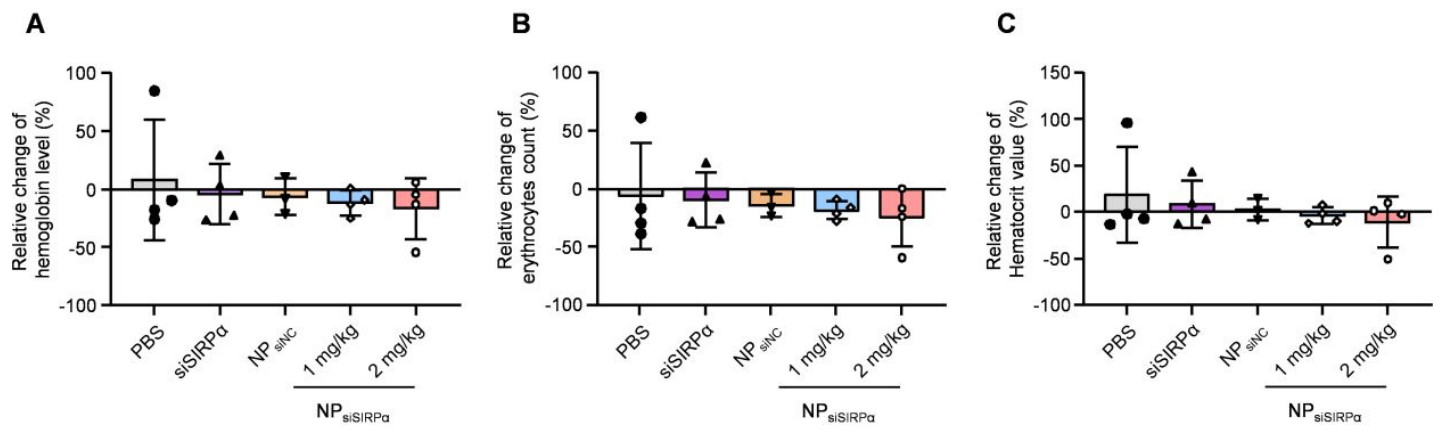

Figure S4. $\mathbf{N P}_{\text {sisIRPa }}$-mediated silence of SIRPa didn't induce obvious hemolytic anemia.

(A-C) Relative changes of the hemoglobin level (A), erythrocytes count (B) and hematocrit value (C) of the mice treated with $\mathrm{NP}_{\text {siSIRP } \alpha}(1$ or $2 \mathrm{mg} / \mathrm{kg}$ siSIRP $\alpha$ ) or other controls. The data are shown as the mean \pm s.d. of $n=3-4$. No significant differences are detected in Figure S2AS2C, one-way ANOVA with Tukey's multiple comparisons test. 

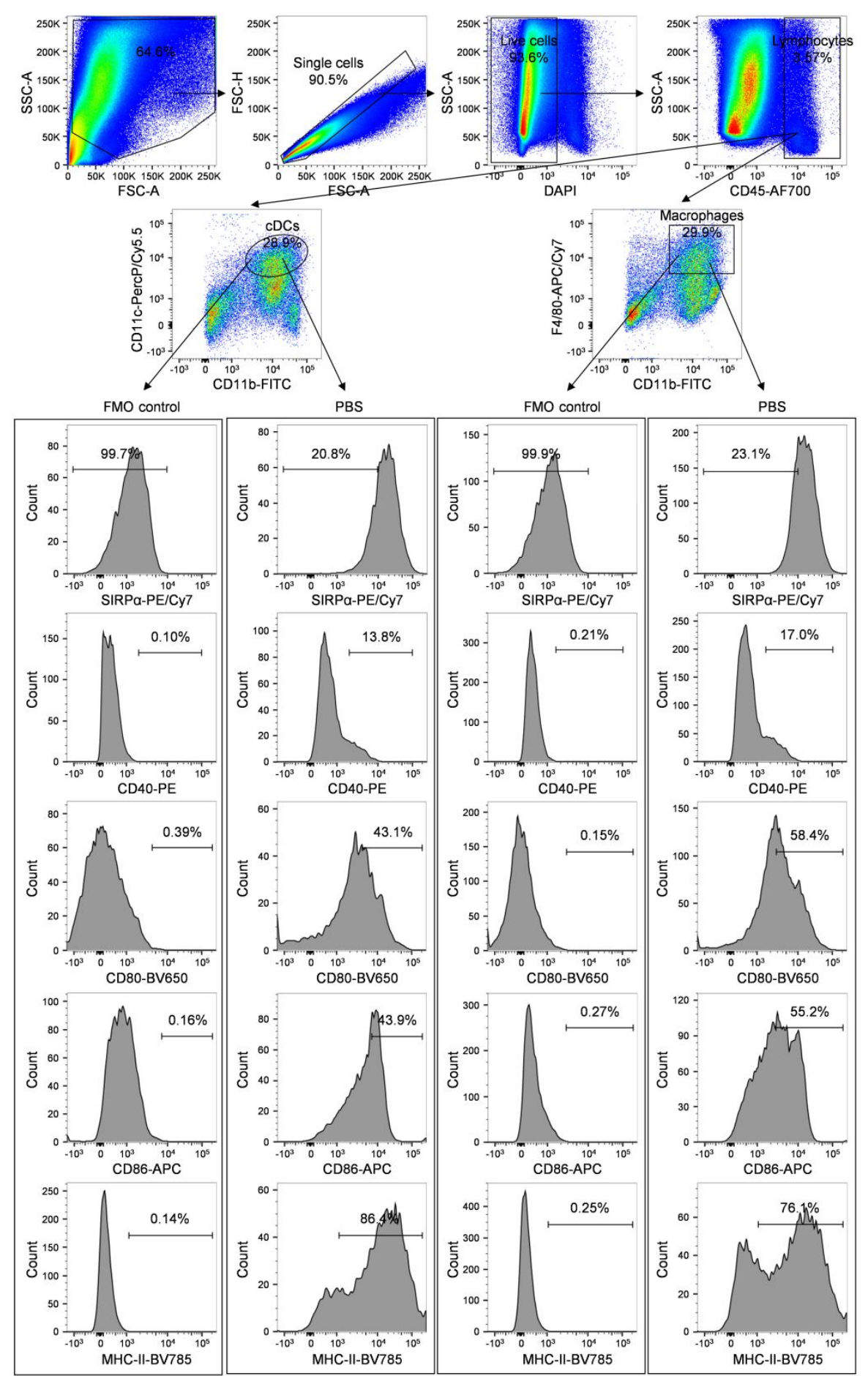

Figure S5. Gating strategies of flow cytometry analysis of the expression of SIRP $\alpha$, CD40, CD80, CD86 and MHC-II on cDCs and macrophages (MФ). cDCs $\left(\mathrm{CD} 11 \mathrm{~b}^{+} \mathrm{CD} 11 \mathrm{c}^{+}\right)$and $\mathrm{M} \Phi\left(\mathrm{CD} 11 \mathrm{~b}^{+} \mathrm{F} 4 / 80^{+}\right)$were isolated from the melanoma tissue of mice bearing OVA-B16-F10 melanoma after the last measurement of the tumor volume at day 18 post tumor xenograft. FMO (Fluorescence minus one) controls were samples that contained all the antibodies we were testing in our experimental samples (including PBS group), minus one of them. 

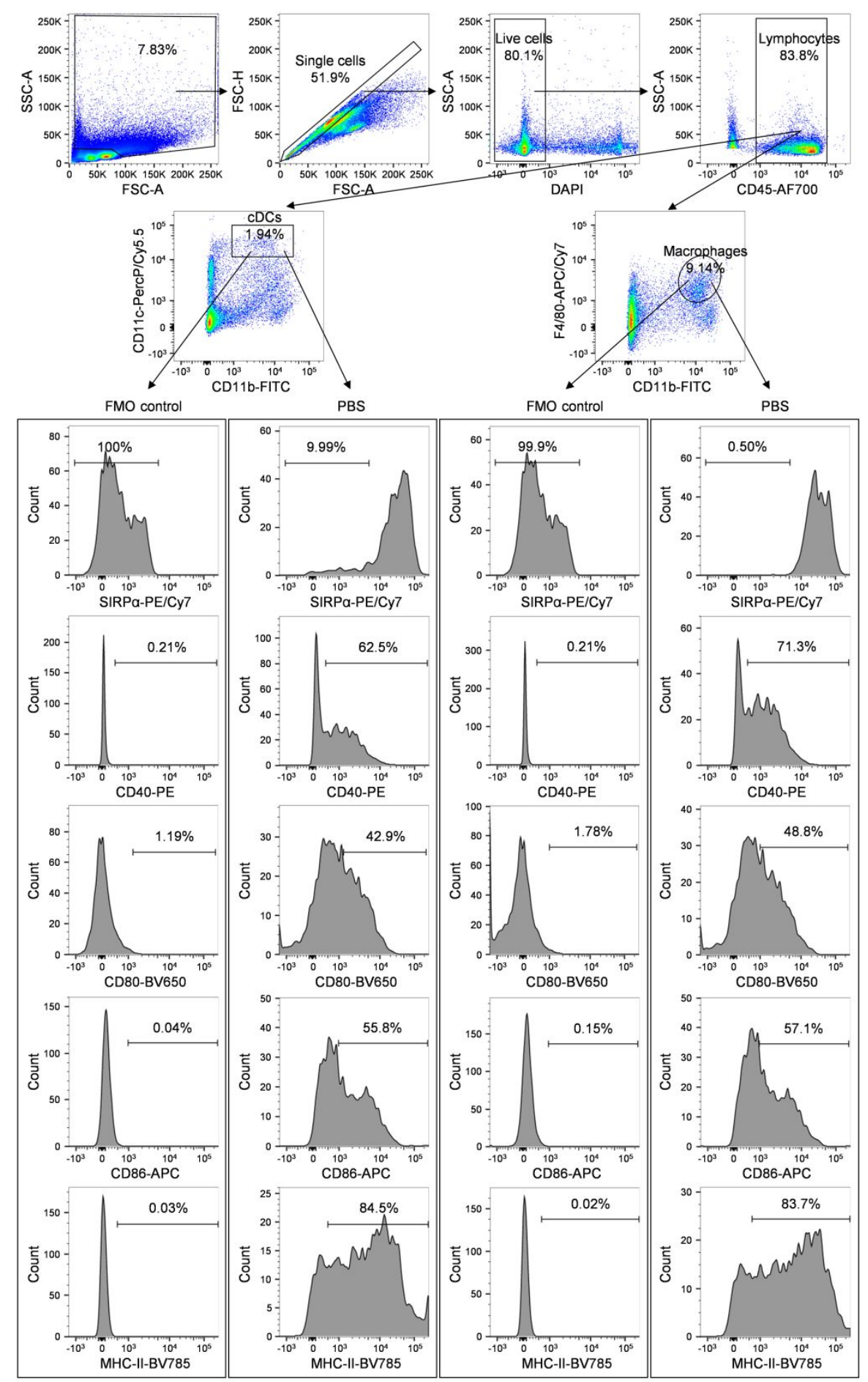

Figure S6. Gating strategies of flow cytometry analysis of the expression of SIRP $\alpha$, CD40, CD80, CD86 and MHC-II on cDCs and MФ. cDCs $\left(\mathrm{CD} 11 \mathrm{~b}^{+} \mathrm{CD} 11 \mathrm{c}^{+}\right)$and $\mathrm{M} \Phi$ $\left(\mathrm{CD} 11 \mathrm{~b}^{+} \mathrm{F} 4 / 80^{+}\right)$were isolated from the tumor-draining lymph nodes (tDLN) of mice bearing OVA-B16-F10 melanoma after the last measurement of the tumor volume at day 18 post tumor xenograft. 

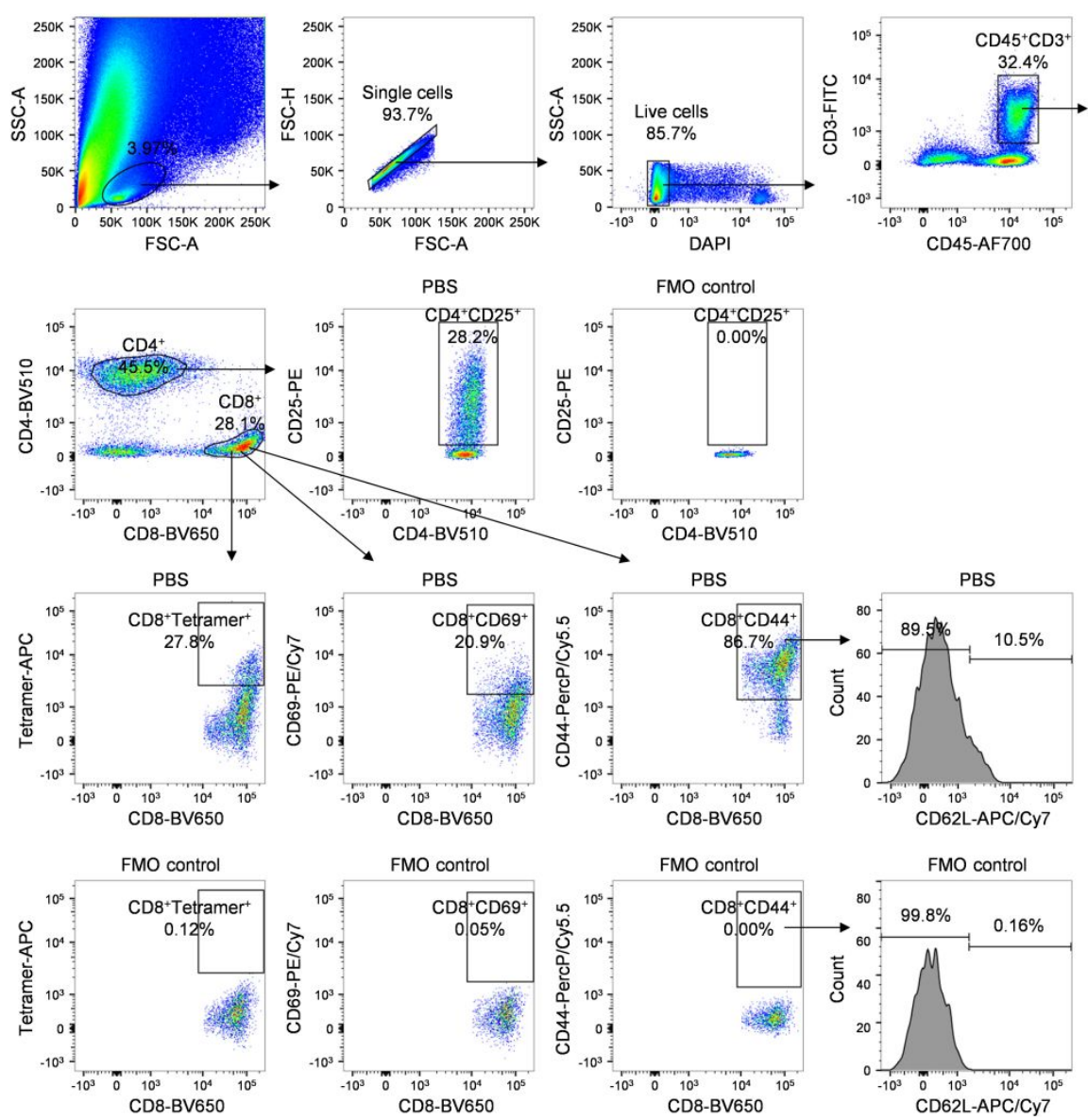

Figure S7. Gating strategies of flow cytometry analysis of the subtypes of $T$ cells in the melanoma microenvironment. $\mathrm{T}$ cells were isolated from the melanoma tissue of mice bearing OVA-B16-F10 melanoma after the last measurement of the tumor volume at day 18 post tumor xenograft. $\mathrm{CD} 4^{+} \mathrm{T}$ cells $\left(\mathrm{CD} 3^{+} \mathrm{CD} 4^{+}\right)$, regulatory $\mathrm{T}$ cells $\left(\mathrm{CD} 3^{+} \mathrm{CD} 4^{+} \mathrm{CD} 25^{+}\right), \mathrm{CD} 8^{+}$ cytotoxic $\mathrm{T}$ cells $\left(\mathrm{CD}^{+} \mathrm{CD}^{+}\right)$, OVA-specific $\mathrm{CD} 8^{+} \mathrm{T}$ cells $\left(\mathrm{CD} 3^{+} \mathrm{CD} 8^{+} \mathrm{Tetramer}^{+}\right)$, tissueresident memory $\mathrm{CD}^{+} \mathrm{T}$ cells $\left(\mathrm{CD}^{+} \mathrm{CD} 8^{+} \mathrm{CD} 69^{+}\right)$, central memory $\mathrm{CD} 8^{+} \mathrm{T}$ cells $\left(\mathrm{CD}^{+} \mathrm{CD}^{+} \mathrm{CD}^{+} 4^{+} \mathrm{CD} 62 \mathrm{~L}^{\text {high }}\right)$ and effector memory $\mathrm{CD} 8^{+} \mathrm{T}$ cells $\left(\mathrm{CD} 3{ }^{+} \mathrm{CD} 8{ }^{+} \mathrm{CD} 44^{+} \mathrm{CD} 62 \mathrm{~L}^{\text {low }}\right)$ were analyzed separately. 

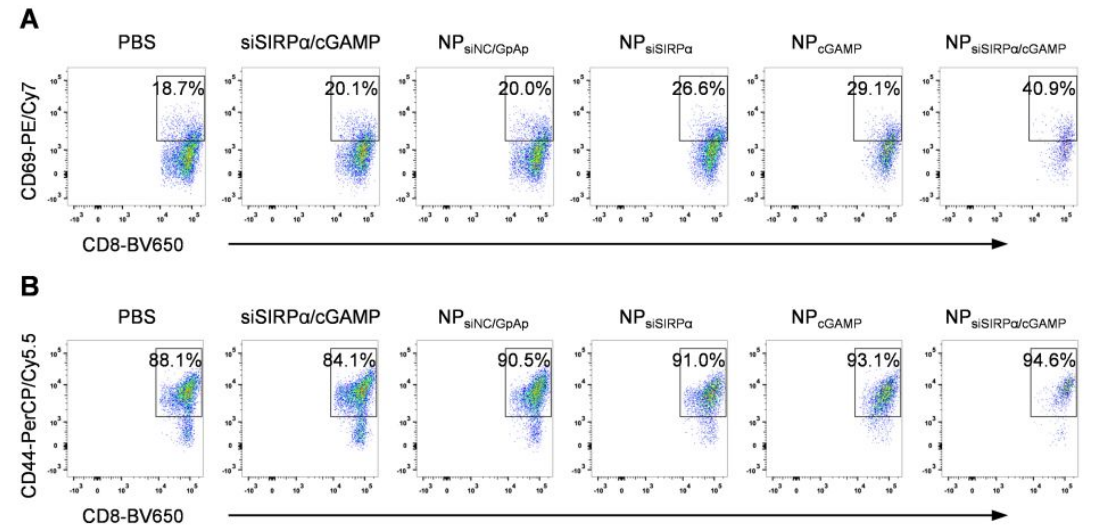

C
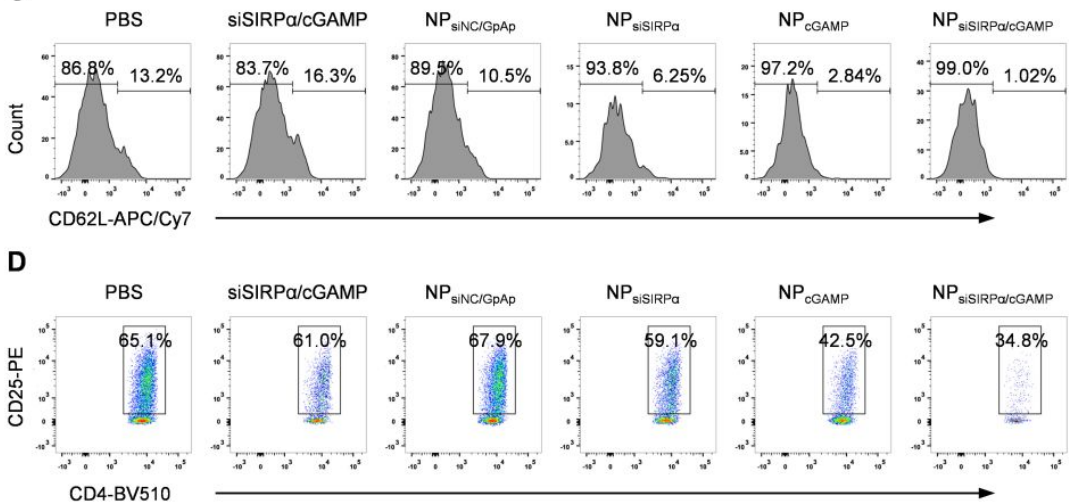

Figure S8. Representative flow cytometry data of the percentages of different $T$ cells subtypes in the melanoma microenvironment. (A) The percentages of tissue-resident memory $\mathrm{CD} 8^{+} \mathrm{T}$ cells $\left(\mathrm{CD} 8^{+} \mathrm{CD} 69^{+}\right)$in $\mathrm{CD} 8^{+} \mathrm{T}$ cells. (B) The percentages of memory $\mathrm{CD} 8^{+} \mathrm{T}$ cells $\left(\mathrm{CD} 8{ }^{+} \mathrm{CD} 44^{+}\right)$in $\mathrm{CD} 8^{+} \mathrm{T}$ cells. (C) The percentages of central memory $\mathrm{T}$ cells $\left(\mathrm{CD} 62 \mathrm{~L}^{\text {high }}\right)$ and effector memory $\mathrm{T}$ cells $\left(\mathrm{CD} 62 \mathrm{~L}^{\text {low }}\right)$ in $\mathrm{CD} 8^{+} \mathrm{CD} 44^{+} \mathrm{T}$ cells. (D) The percentages of regulatory $\mathrm{T}$ cells $\left(\mathrm{CD} 4^{+} \mathrm{CD} 25^{+}\right)$in $\mathrm{CD} 4^{+} \mathrm{T}$ cells. The gating strategies were shown in Figure S7. 

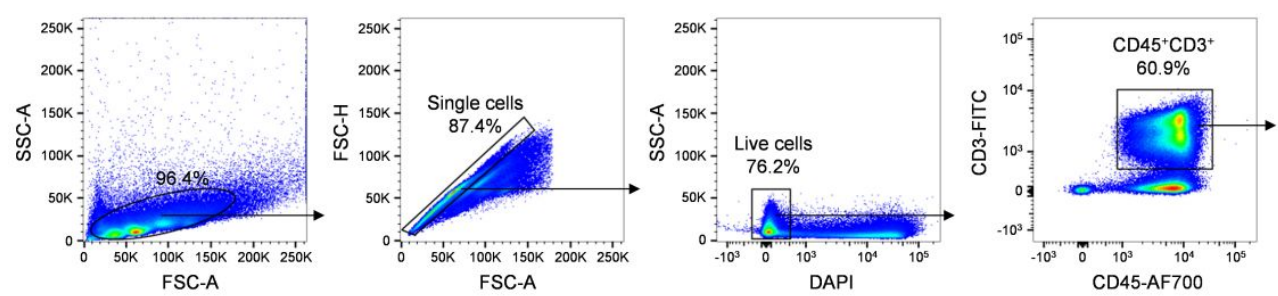

PBS
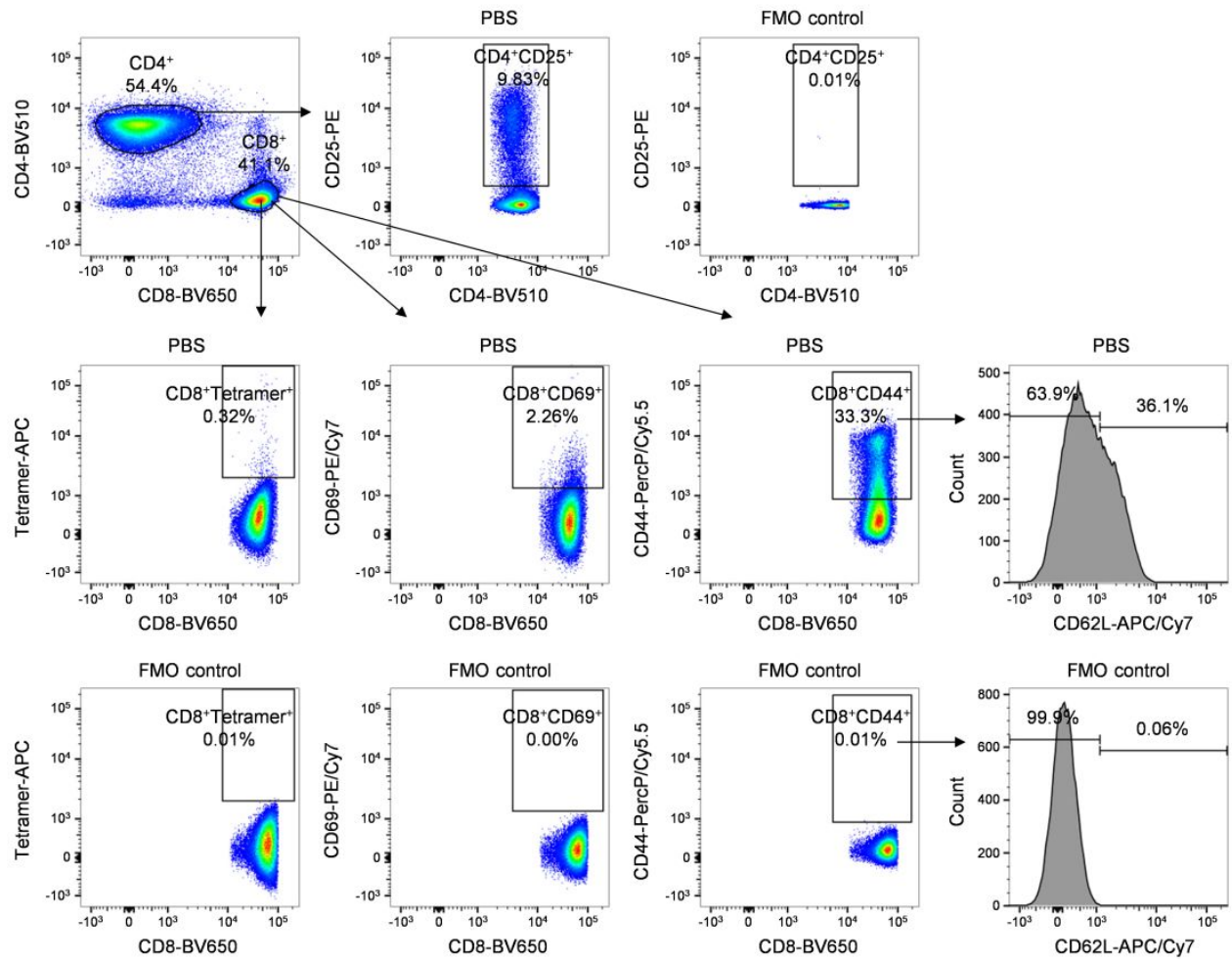

Figure S9. Gating strategies of flow cytometry analysis of the subtypes of $T$ cells in the tumor-draining lymph nodes (tDLN). T cells were isolated from the tDLN of mice bearing OVA-B16-F10 melanoma after the last measurement of the tumor volume at day 18 post tumor xenograft. $\mathrm{CD} 4^{+} \mathrm{T}$ cells $\left(\mathrm{CD}^{+} \mathrm{CD}^{+}\right)$, regulatory $\mathrm{T}$ cells $\left(\mathrm{CD}^{+}{ }^{+} \mathrm{CD} 4^{+} \mathrm{CD} 25^{+}\right), \mathrm{CD} 8^{+}$cytotoxic $\mathrm{T}$ cells $\left(\mathrm{CD} 3^{+} \mathrm{CD} 8^{+}\right)$, OVA-specific $\mathrm{CD}^{+} \mathrm{T}$ cells $\left(\mathrm{CD}^{+}{ }^{+} \mathrm{CD} 8^{+} \mathrm{Tetramer}^{+}\right)$, tissue-resident memory $\mathrm{CD}^{+} \quad \mathrm{T}$ cells $\left(\mathrm{CD} 3^{+} \mathrm{CD} 8^{+} \mathrm{CD} 69^{+}\right)$, central memory $\mathrm{CD} 8^{+} \quad \mathrm{T}$ cells $\left(\mathrm{CD}^{+} \mathrm{CD} 8{ }^{+} \mathrm{CD} 44^{+} \mathrm{CD} 62 \mathrm{~L}^{\text {high }}\right)$ and effector memory $\mathrm{CD} 8^{+} \mathrm{T}$ cells $\left(\mathrm{CD} 3{ }^{+} \mathrm{CD} 8{ }^{+} \mathrm{CD} 44^{+} \mathrm{CD} 62 \mathrm{~L}^{\text {low }}\right)$ were analyzed separately. 

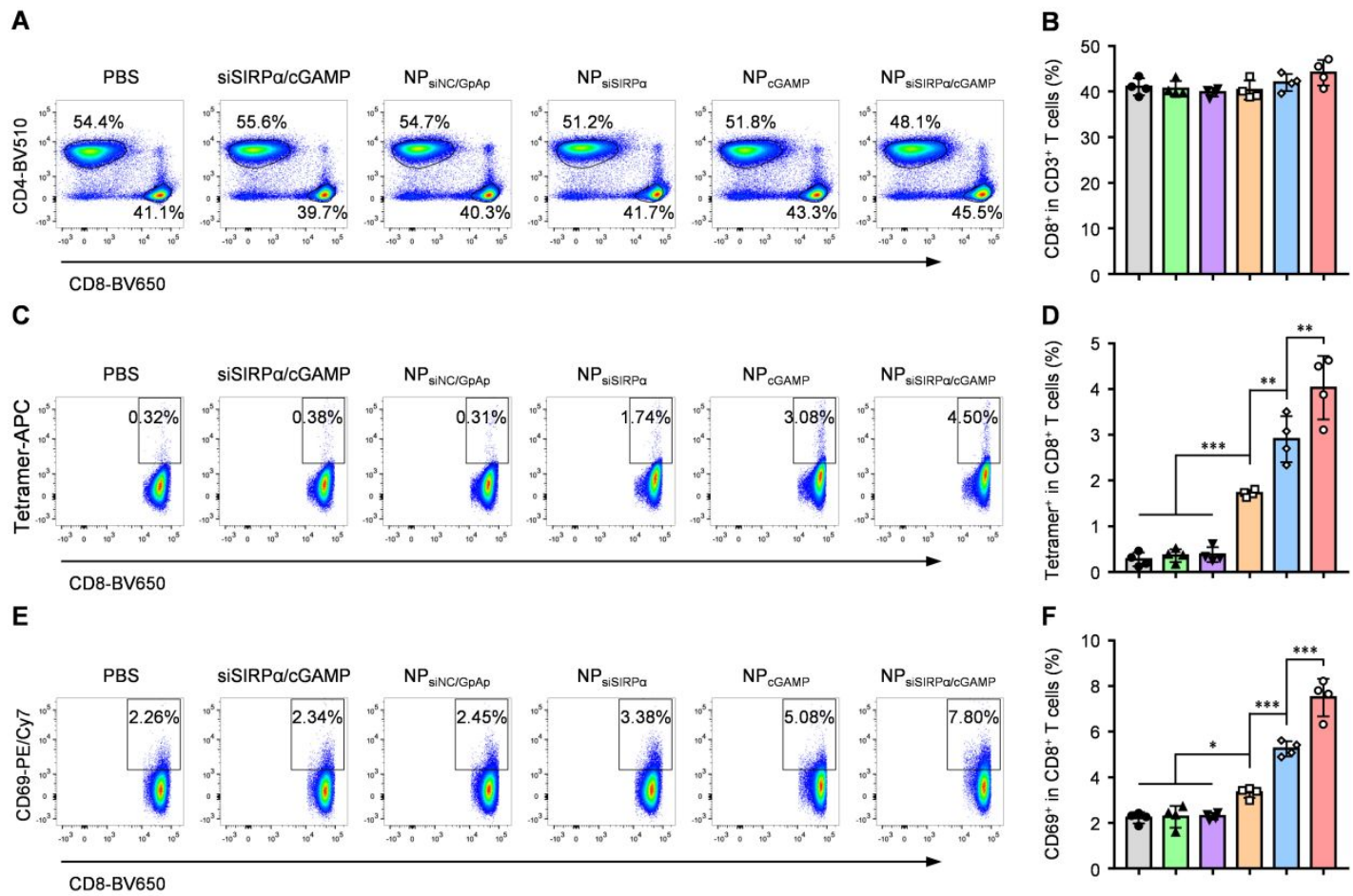

G

H
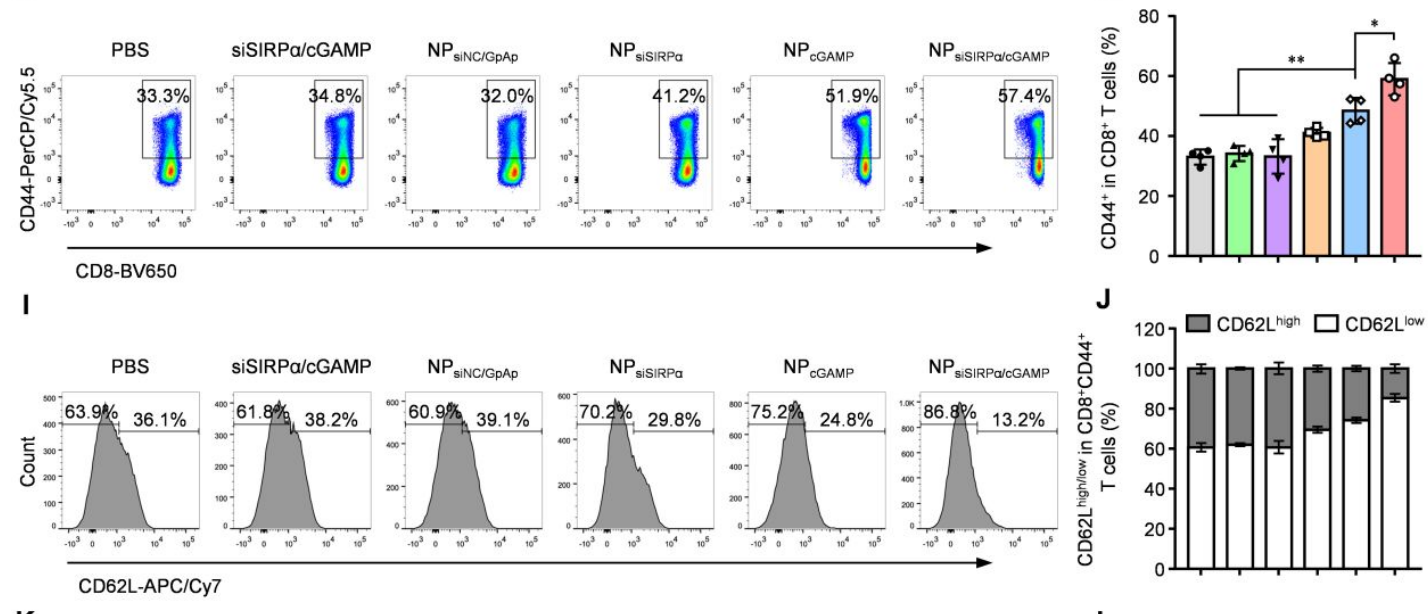

K

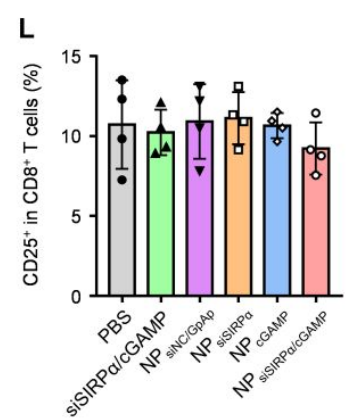

Figure S10. Flow cytometry analysis of the percentages of different $T$ cells subtypes of in the tDLN. (A, B) Representative flow cytometry data (A) and statistical data (B) of the percentages of $\mathrm{CD} 8^{+}$cytotoxic $\mathrm{T}$ cells $\left(\mathrm{CD} 3^{+} \mathrm{CD} 8^{+}\right)$in $\mathrm{CD} 3^{+} \mathrm{T}$ cells. $(\mathrm{C}, \mathrm{D})$ Representative flow cytometry data (C) and statistical data (D) of the percentages of OVA-specific CD8 ${ }^{+} \mathrm{T}$ cells $\left(\mathrm{CD} 8^{+}\right.$Tetramer $\left.^{+}\right)$in $\mathrm{CD}^{+} \mathrm{T}$ cells. $(\mathrm{E}, \mathrm{F})$ Representative flow cytometry data (E) and statistical 
data $(\mathrm{F})$ of the percentages of tissue-resident memory $\mathrm{CD} 8^{+} \mathrm{T}$ cells $\left(\mathrm{CD} 8^{+} \mathrm{CD} 69^{+}\right)$in $\mathrm{CD} 8^{+} \mathrm{T}$ cells. $(\mathrm{G}, \mathrm{H})$ Representative flow cytometry data $(\mathrm{G})$ and statistical data $(\mathrm{H})$ of the percentages of memory $\mathrm{CD}^{+} \mathrm{T}$ cells $\left(\mathrm{CD} 8{ }^{+} \mathrm{CD} 44^{+}\right)$in $\mathrm{CD}^{+} \mathrm{T}$ cells. (I, J) Representative flow cytometry data (I) and statistical data (J) of the percentages of central memory T cells (CD62 $\mathrm{L}^{\text {high }}$ ) and effector memory $\mathrm{T}$ cells $\left(\mathrm{CD} 62 \mathrm{~L}^{\text {low }}\right)$ in $\mathrm{CD} 8^{+} \mathrm{CD} 44^{+} \mathrm{T}$ cells. $(\mathrm{K}, \mathrm{L})$ Representative flow cytometry data $(\mathrm{K})$ and statistical data $(\mathrm{L})$ of the percentages of regulatory $\mathrm{T}$ cells $\left(\mathrm{CD} 4^{+} \mathrm{CD} 25^{+}\right)$ in $\mathrm{CD}^{+} \mathrm{T}$ cells. The gating strategies were shown in Figure S9. The data are shown as the mean \pm s.d. of $\mathrm{n}=4(\mathrm{~B}, \mathrm{D}, \mathrm{F}, \mathrm{H}, \mathrm{J}, \mathrm{L})$. Significant differences are indicated by $* P<0.05, * * P<$ $0.01, * * * P<0.001$, one-way ANOVA with Tukey's multiple comparisons test.

Table S1. Primers for qRT-PCR analysis.

\begin{tabular}{|c|l|}
\hline Primers ID & \multicolumn{1}{|c|}{ Sequence } \\
\hline SIRP $\alpha$ forward primer & 5'-GTGCTTTGCTCGTAGTCCTG-3' \\
\hline SIRP $\alpha$ reverse primer & 5'-GGGTTATTTCCCTGGCGTTC-3' \\
\hline IFN- $\alpha$ forward primer & 5'-TCCCCTGACCCAGGAAGATGCC-3' \\
\hline IFN- $\alpha$ reverse primer & 5'-ATTGGCAGAGGAAGACAGGGCT-3' \\
\hline IFN- $\beta$ forward primer & 5'-TGAACTCCACCAGCAGACA-3' \\
\hline IFN- $\beta$ reverse primer & 5'-ACCACCATCCAGGCGTAG-3' \\
\hline GAPDH forward primer & 5'-GGGTCCCAGCTTAGGTTCAT-3' \\
\hline GAPDH reverse primer & 5'-CCAATACGGCCAAATCCGTT-3' \\
\hline
\end{tabular}

